\title{
Interactive effects of temperature, organic carbon, and pipe material on microbiota composition and Legionella pneumophila in hot water plumbing systems
}

\author{
Caitlin R. Proctor ${ }^{1,2+}$, Dongjuan Dai ${ }^{1 \dagger}$, Marc A. Edwards ${ }^{1}$ and Amy Pruden ${ }^{1 *}$
}

\begin{abstract}
Background: Several biotic and abiotic factors have been reported to influence the proliferation of microbes, including Legionella pneumophila, in hot water premise plumbing systems, but their combined effects have not been systematically evaluated. Here, we utilize simulated household water heaters to examine the effects of stepwise increases in temperature $\left(32-53^{\circ} \mathrm{C}\right.$ ), pipe material (copper vs. cross-linked polyethylene (PEX)), and influent assimilable organic carbon $(0-700 \mu \mathrm{g} / \mathrm{L})$ on opportunistic pathogen gene copy numbers and the microbiota composition, as determined by quantitative polymerase chain reaction and 16S rRNA gene amplicon sequencing.

Results: Temperature had an overarching influence on both the microbiota composition and L. pneumophila numbers. L. pneumophila peaked at $41^{\circ} \mathrm{C}$ in the presence of PEX $\left(1.58 \times 10^{5}\right.$ gene copies $\left./ \mathrm{mL}\right)$. At $53{ }^{\circ} \mathrm{C}, \mathrm{L}$. pneumophila was not detected. Several operational taxonomic units (OTUs) persisted across all conditions, accounting for $50 \%$ of the microbiota composition from 32 to $49{ }^{\circ} \mathrm{C}$ and $20 \%$ at $53{ }^{\circ} \mathrm{C}$. Pipe material most strongly influenced microbiota composition at lower temperatures, driven by five to six OTUs enriched with each material. Copper pipes supported less L. pneumophila than PEX pipes (mean $2.5 \log _{10}$ lower) at temperatures $\leq 41{ }^{\circ} \mathrm{C}$, but showed no difference in total bacterial numbers. Differences between pipe materials diminished with elevated temperature, probably resulting from decreased release of copper ions. At temperatures $\leq 45^{\circ} \mathrm{C}$, influent assimilable organic carbon correlated well with total bacterial numbers, but not with L. pneumophila numbers. At $53{ }^{\circ} \mathrm{C}$, PEX pipes leached organic carbon, reducing the importance of dosed organic carbon. L. pneumophila numbers correlated with a Legionella OTU and a Methylophilus OTU identified by amplicon sequencing.

Conclusions: Temperature was the most effective factor for the control of L. pneumophila, while microbiota composition shifted with each stepwise temperature increase. While copper pipe may also help shape the microbiota composition and limit L. pneumophila proliferation, its benefits might be constrained at higher temperatures. Influent assimilable organic carbon affected total bacterial numbers, but had minimal influence on opportunistic pathogen gene numbers or microbiota composition. These findings provide guidance among multiple control measures for the growth of opportunistic pathogens in hot water plumbing and insight into the mediating role of microbial ecological factors.
\end{abstract}

Keywords: Hot water, Premise plumbing, Legionella, Opportunistic pathogen, Temperature control, Pipe material

\footnotetext{
* Correspondence: apruden@vt.edu

'Equal contributors

'Via Department of Civil and Environmental Engineering, Virginia Tech,

Blacksburg, Virginia 24061, USA

Full list of author information is available at the end of the article
} 


\section{Background}

Preventing proliferation of opportunistic pathogens (OPs) in building plumbing is an important step in delivery of safe drinking water to consumers. In particular, Legionella pneumophila is an OP that has become the leading cause of drinking-water-related disease in developed countries [1]. L. pneumophila is especially challenging to control because it establishes and grows as part of the native plumbing microbiota, even under oligotrophic conditions and in the presence of disinfectants. L. pneumophila can thrive in biofilms, partly owing to the protection provided by amoeba hosts, inside which they preferentially amplify [2]. Some amoebae occurring in drinking water, such as Acanthaomeba spp. and Naegleria fowleri, are also OPs [3-5]. In considering options for intentionally shaping the microbiota in building plumbing systems, temperature and pipe material are practical factors that can be directly controlled at the building level, while assimilable organic carbon (AOC) is influenced by both municipal water treatment and conditions in the building plumbing.

Elevating the water temperature $>60{ }^{\circ} \mathrm{C}$ can be highly effective for killing and inhibiting $L$. pneumophila and other OPs $[6,7]$. However, the reality is that such "hot" temperatures are difficult to maintain throughout the system, resulting in "warm" water conditions that are highly conducive to pathogen growth in much of the building plumbing environment [8]. Water heaters pose a risk for promoting microbial illness when operated between 30 and $54{ }^{\circ} \mathrm{C}$ [9] or whenever the water coming out of the heaters is below $60{ }^{\circ} \mathrm{C}$ or fails to remain consistently above $55^{\circ} \mathrm{C}$ throughout the premise plumbing [10]. Despite the well-established benefits of elevated temperatures for OP control, some guidelines for water heater operation recommend temperatures as low as $48{ }^{\circ} \mathrm{C}[11,12]$ because of concerns about scalding, scaling, and energy conservation, with only some recommending higher temperatures [13-15]. Besides direct effects on pathogens, temperature is a fundamental selective force in shaping the broader microbiota of tap water [16].

Within a building, pipes and plumbing components are made from a vast array of materials, all with the potential to influence microbial regrowth [17]. The high surface area to volume ratio in the home compared to that of the main water distribution system can exacerbate microbial growth, while the higher temperatures encountered in hot water lines can mediate the influence of materials [17, 18]. Plastic pipes, especially cross-linked polyethylene (PEX), can release substantial amounts of organic carbon, stimulating growth of heterotrophic bacteria and amoebae [18-21]. Plastic pipes can also release phosphate, antioxidants, and complex non-biodegradable organics [19, 22, 23]. Copper, on the other hand, has antimicrobial properties and is commonly applied together with silver for on-site disinfection $[24,25]$. However, when used as a pipe material, the disinfectant properties of copper can vary [26-29]. For example, in one model distribution system, copper pipe seemed to control L. pneumophila growth, but only for a limited time [21], while in a field study, positive correlations between copper fixtures of unknown age and L. pneumophila were noted [29]. Another study found no difference in Legionella spp. abundance associated with PEX versus copper in an office building, but did note that copper suppressed other potential OPs (i.e., mycobacteria), demonstrating that different OPs can vary in their associations with materials and that individual microbiota members can behave differently [16].

Limiting the levels of nutrients in treated and distributed water could enable water utilities to reduce risk of pathogen regrowth at the community-scale. AOC is a common target, with proposed limits of $10 \mu \mathrm{g} / \mathrm{L}$ [30] and $32 \mu \mathrm{g} / \mathrm{L}$ [31] in non-disinfected water or $100 \mu \mathrm{g} / \mathrm{L}$ in water carrying disinfectant residual [32]. However, it is important to also consider that AOC can be produced during distribution and in building plumbing, for example, via nitrifying and other autotrophic organisms [33] or through leaching from plastic pipes [34]. Moreover, expectations for AOC control have been based on studies of distribution system water under continuous-flow conditions, whereas premise plumbing operates under warm semi-stagnant conditions. A prior controlled study simulating the premise plumbing environment noted that total organic carbon level was not the master variable controlling proliferation of L. pneumophila or Mycobacterium avium [35].

Here, we employed simulated water heaters (SWH) to establish a fundamental understanding of interactive effects of temperature, pipe material, and AOC levels on the microbiota structure and L. pneumophila numbers with time. SWHs were equipped with copper or PEX pipe sections, dosed in triplicate with AOC from 0 to $700 \mu \mathrm{g} / \mathrm{L}$, and subject to an incrementally increased temperature regime. Effects of copper pipe were further explored in complementary experiments in which $\mathrm{Cu}^{2+}$ was dosed into SWHs. In addition to Illumina amplicon sequencing of 16S rRNA genes, L. pneumophila, Vermamoeba vermiformis, and Acanthamoeba spp. gene markers were monitored by quantitative polymerase chain reaction (qPCR). Insights gained help understand how the microbiota composition is shaped, intentionally and unintentionally, in hot water plumbing systems.

\section{Methods}

\section{Temperature experiment}

\section{Simulated water heaters (SWHs)}

SWHs consisted of $125-\mathrm{mL}$ glass bottles equipped with PEX or copper pipe sections $\left(8 \Phi^{1 / 2}\right.$ in. $\left.\times 1.25 \mathrm{~cm}\right)$, a $2-\mathrm{mm}$ layer of glass beads $(\Phi 1 \mathrm{~mm})$, and polytetrafluoroethylene caps. SWHs were operated at $32{ }^{\circ} \mathrm{C}$ for 2.5 years prior to the present study. During the 2.5 years, SWHs were initially 
fed with synthesized water and/or Blacksburg tap water (water was treated the same way as described previously [35], unfiltered with $0.45-\mu \mathrm{m}$ filters) to allow the development of mature and complex drinking water biofilms in SWHs. SWHs were also inoculated with approximately $2.03 \times 10^{5}$ gene copies/mL L. pneumophila (ATCC 33152, $33733,33734,33823$, a mixture of environmental isolates, to maximize the likelihood that L. pneumophila established in the systems), $2.08 \times 10^{3}$ gene copies $/ \mathrm{mL}$ Acanthamoeba polyphaga (ATCC 30871), and $1.46 \times 10^{3}$ amoeba/mL Vermamoeba vermiformis (ATCC 50237) after the first 4 months of the 2.5 years. On day 0 of the present study (defined as 2.5 years after initial setup), SWHs were crossinoculated during a routine water change by pooling $100 \mathrm{~mL}$ water from each, mixing, and returning $1 \mathrm{~mL}$ of the mixture to each SWH together with $100 \mathrm{~mL}$ freshly prepared influent (details below). Cross-inoculation was done in this manner to limit interruptions to delivery of fresh nutrients during normal water changes.

\section{Water changes}

Influent water was prepared from local Blacksburg, VA, water, which is usually chloraminated. Influent was prepared by breakpoint chlorinating cold tap water through incremental addition of chlorine while measuring total residual chlorine using the Hach reagent Powder Pillows (Loveland, CO), totaling 2-5 mg/L chlorine addition. As per breakpoint chlorination kinetics with chloraminated waters, residual chlorine level initially increased, then decreased and increased again at the breakpoint, when chlorine addition was stopped. Breakpoint chlorinated water was further prepared by heating it to $90{ }^{\circ} \mathrm{C}$ for $10 \mathrm{~min}$, passing it through a biologically active granular activated carbon (GAC) filter (Undercounter Standard Filter Unit, Model GX1S01R, General Electric, Fairfield, $\mathrm{CT}$ ), filtering with a $0.45-\mu \mathrm{m}$ polyvinylidene fluoride (PVDF) filter to remove colloidal carbon particles and most microbes to lower background carbon level and to reduce seasonal variations in influent water microbiota, and adjusting the $\mathrm{pH}$ to $7.5 \pm 0.1$. Three times a week, 100 of the $120 \mathrm{~mL}$ total volume was gently decanted (i.e., without mixing) and replaced with freshly prepared influent water. Water changes and sample collection were conducted using aseptic technique.

Five levels of influent AOC were investigated by dosing influent water with an acetate and glucose mixture $(0,5,30,150$, and $700 \mu \mathrm{g} C / \mathrm{L})$. While organic carbon in drinking water is typically complex in nature and not directly assimilable, as it is largely derived from natural organic matter and plumbing components, acetate and glucose were selected because they are highly assimilable by a wide variety of bacteria, common intermediates of degradation of more complex organic carbon forms, and commonly employed in assimilable organic carbon assays [36]. Triplicate SWHs represented each pipe material and AOC level.

\section{Temperature experiment}

Temperature was elevated in a stepwise fashion $\left(2.5-4^{\circ}\right.$ C every 5-7 weeks) in all SWHs, except for an extra temperature control set for each pipe material maintained at $32{ }^{\circ} \mathrm{C}$ and receiving $700 \mu \mathrm{g} / \mathrm{L}$ AOC. Samples were collected during regular water changes at the end of each temperature period, specifically, on days 1, 27, $58,106,141,183,224,267$, and 316 , with temperatures of $32,32,32,34.5,37,41,45,49,53{ }^{\circ} \mathrm{C}$, respectively.

Temperature was maintained with a New Brunswick Scientific Classic Series C24 Incubator Shaker (Edison, NJ, USA). Upon malfunction on days 274 and 277, SWHs were transferred to a New Brunswick Scientific Innova 43 Incubator Shaker (Edison, NJ, USA) for the remainder of the experiment. During malfunction, the incubator reached $60{ }^{\circ} \mathrm{C}$ for no more than $24 \mathrm{~h}$.

\section{$\mathrm{Cu}^{2+}$ dosing experiment}

Six new SWHs were established to investigate the impact of copper ion $\left(\mathrm{Cu}^{2+}\right)$ dosing. These new glass bottles were amended with PEX pipe sections (8 $\Phi$ $1 / 2$ in. $\times 1.2 \mathrm{~cm}$ ) and incubated at $32{ }^{\circ} \mathrm{C}$. Water was prepared and changed as described above (no AOC dosed) three times per week. In week one (3 times change), influent was spiked with $34 \mathrm{~mL}$ pooled effluent from the temperature experiment SWHs. Starting from day 22, influent $\mathrm{pH}$ was adjusted from 7.5 to 7.0. Soluble $\mathrm{Cu}^{2+}$ was dosed into three SWHs at increasing levels $(0,5,30$, 150 , and $1000 \mu \mathrm{g} / \mathrm{L})$ using a stock $0.0014 \mathrm{M} \mathrm{CuSO}_{4}$ solution with 14 days between every increase, while the other three SWHs served as controls with no $\mathrm{Cu}^{2+}$ dosing. This experiment was run for a total of 90 days.

\section{Copper ions}

Copper ions $\left(\mathrm{Cu}^{2+}\right)$ were measured using inductively coupled plasma mass spectrometry (ICP-MS). Ten milliliter from each SWH were acidified by adding $2 \%$ nitric acid by mass prior to analysis. Soluble copper was operationally defined by that passing through a $0.45-\mu \mathrm{m}$ pore size filter.

\section{Total organic carbon}

Total organic carbon (TOC) was measured with a Sievers $5310 \mathrm{C}$ Laboratory TOC-MS Analyzer using the Data Pro 5310 C Computer Program. Samples were analyzed using $30 \mathrm{~mL}$ from each $\mathrm{SWH}$ or by pooling $10 \mathrm{~mL}$ from each triplicate SWH. Samples were acidified with phosphoric acid and sparged with $\mathrm{N}_{2}$ gas to purge inorganic carbon prior to analysis. 


\section{DNA extraction}

One hundred milliliter of SWH water was filtered onto sterile $0.22-\mu \mathrm{m}$ pore size mixed cellulose ester filters (Millipore, Billerica, MA, USA). DNA was extracted using the FastDNA ${ }^{\bullet}$ SPIN Kit (MP Biomedicals, Solon, $\mathrm{OH}$, USA) according to the manufacturer's instructions.

\section{Quantitative polymerase chain reaction}

The quantitative polymerase chain reaction (qPCR) method was applied to quantify the macrophage infectivity potentiator (mip) gene specific to L. pneumophila [37], the 18S rRNA gene of $V$. vermiformis [38], the $18 \mathrm{~S}$ rRNA gene of Acanthamoeba [39], and bacterial 16S rRNA genes [40] using protocols previously optimized for drinking water samples [41]. Q-PCR was carried out using a CFX96 ${ }^{\text {mi }}$ Real Time system (Bio-Rad, Hercules, CA, USA), including a calibration curve of seven to eight points and negative controls in each run.

\section{Culturing}

Culturing for detection of L. pneumophila was conducted by heating $100 \mu \mathrm{L}$ water samples to $50{ }^{\circ} \mathrm{C}$ for $30 \mathrm{~min}$ and directly plating onto buffered charcoal yeast extract (BCYE) agar according to published methods $[41,42]$.

\section{Illumina 16S rRNA gene amplicon sequencing}

Illumina amplicon sequencing of bacterial 16S rRNA genes was applied to triplicate SWHs corresponding to both pipe materials, three levels of dosed $\operatorname{AOC}(0,30$, and $700 \mu \mathrm{g} / \mathrm{L})$, and six temperature levels $(32,37,41,45$, 49 , and $53{ }^{\circ} \mathrm{C}$ ), along with corresponding constant temperature controls sampled on the same days (days 58, 141, 183, 224, 267, and 316). 16S rRNA genes were amplified with barcoded primers targeting the V4 region according to the Earth Microbiome Project Illumina Amplification Protocol [43], followed by sequencing with an Illumina MiSeq Sequencer $(2 \times 250 \mathrm{bp})$ at the Virginia Bioinformatics Institute (Blacksburg, VA, USA). Sequences were deposited to the European Nucleotide Archive under project accession number PRJEB11665.

\section{Data analysis}

Microbial numbers (gene copies $/ \mathrm{mL}$ water) were logtransformed $\left[\log _{10}(\mathrm{x}+1)\right]$, with $L$. pneumophila numbers below detection treated as zero. $T$ tests and correlation analyses were performed in JMP Pro 12 (Cary, NC, USA). 16S rRNA gene sequences were analyzed in mothur (1.36.0). Sequences with an average similarity $\geq 97 \%$ were assigned an operational taxonomic unit (OTU). Each sample was rarefied to 12,430 sequences for comparison. Alpha and beta diversities were determined as mean values of 1000 random rarefactions. Bray-Curtis similarity matrix and jclass matrix were applied to analysis of similarity (ANOSIM) in mothur, non-metric multi-dimensional scaling (NMDS) in Primer-E 6.0 (Plymouth, UK), and Adonis in R. Adonis analysis served to quantify the relative influences of temperature, pipe material, and dosed AOC level in shaping the hot water microbiota composition. "Persistent" OTUs were defined as being detected at all temperatures for any AOC level after rarifying to 12,430 sequences/sample. "Enriched" OTUs were those OTUs firstly identified by an indicator in mothur and then selected either having an indicator value $>80$ or a relative abundance $>1 \%$.

\section{Results}

\section{Total bacterial numbers}

AOC was amended to the SWHs as glucose and acetate and directly measured as TOC in the SWH influent and effluent at two time points, corresponding to the 37 and $53{ }^{\circ} \mathrm{C}$ experimental conditions. Influent TOC $\left(\mathrm{TOC}_{\text {in }}\right)$ was confirmed to be proportional to the dosed AOC $(\rho=0.89-0.99)$ (Additional file 1: Fig. S1A). $\Delta$ TOC $\left(\triangle \mathrm{TOC}=\mathrm{TOC}_{\mathrm{in}}-\mathrm{TOC}_{\text {out }}\right)$ was calculated to represent reduction in organic carbon due to biodegradation and TOC generated (e.g., via autotrophy or leaching from pipes). At $37{ }^{\circ} \mathrm{C}, \triangle \mathrm{TOC}$ was positive (i.e., highly amenable to biodegradation) and correlated with dosed AOC for both pipe materials (Pearson correlation coefficient $\rho=0.87-0.88$ ) (Additional file 1: Fig. S1B). At $53{ }^{\circ} \mathrm{C}$, $\triangle \mathrm{TOC}$ in SWHs with copper pipe remained low, regardless of the level of dosed AOC, suggesting that biodegradation was somewhat inhibited. $\triangle \mathrm{TOC}$ values in SWHs with PEX pipe were consistently negative (TOCout $>\mathrm{TOC}_{\mathrm{in}}$ ), indicating leaching of organic carbon from PEX pipe. Under conditions amenable to biodegradation (37 ${ }^{\circ} \mathrm{C}$ with both pipe materials and $53{ }^{\circ} \mathrm{C}$ with copper), $\triangle T O C$ was strongly correlated with total bacterial numbers (measured as 16S rRNA gene copy numbers) $(\rho=0.87, p<0.0001)$ (Additional file 1: Fig. S2), consistent with microbial activity consuming TOC.

The effect of temperature was evaluated by comparing SWHs supplemented with $700 \mu \mathrm{g} / \mathrm{L}$ AOC and incubated at sequentially increasing temperatures versus the control SWHs maintained at $32{ }^{\circ} \mathrm{C}$ and also supplemented with $700 \mu \mathrm{g} / \mathrm{L}$ AOC. Total bacterial numbers in bulk water decreased significantly when temperatures are $\geq$ $45^{\circ} \mathrm{C}(p<0.05)$, while there was no apparent effect of pipe materials on total bacterial numbers at any temperature (Fig. 1a).

An effect of dosed AOC on total bacterial numbers was observed at lower temperatures (Fig. 2a), with positive correlations noted from 32 to $45{ }^{\circ} \mathrm{C}$ (Pearson correlation $\rho=0.39-0.81, p<0.05)$. No correlations were observed between dosed AOC and bacterial numbers at $49{ }^{\circ} \mathrm{C}$ (either pipe material) or $53{ }^{\circ} \mathrm{C}$ (copper pipe), while 

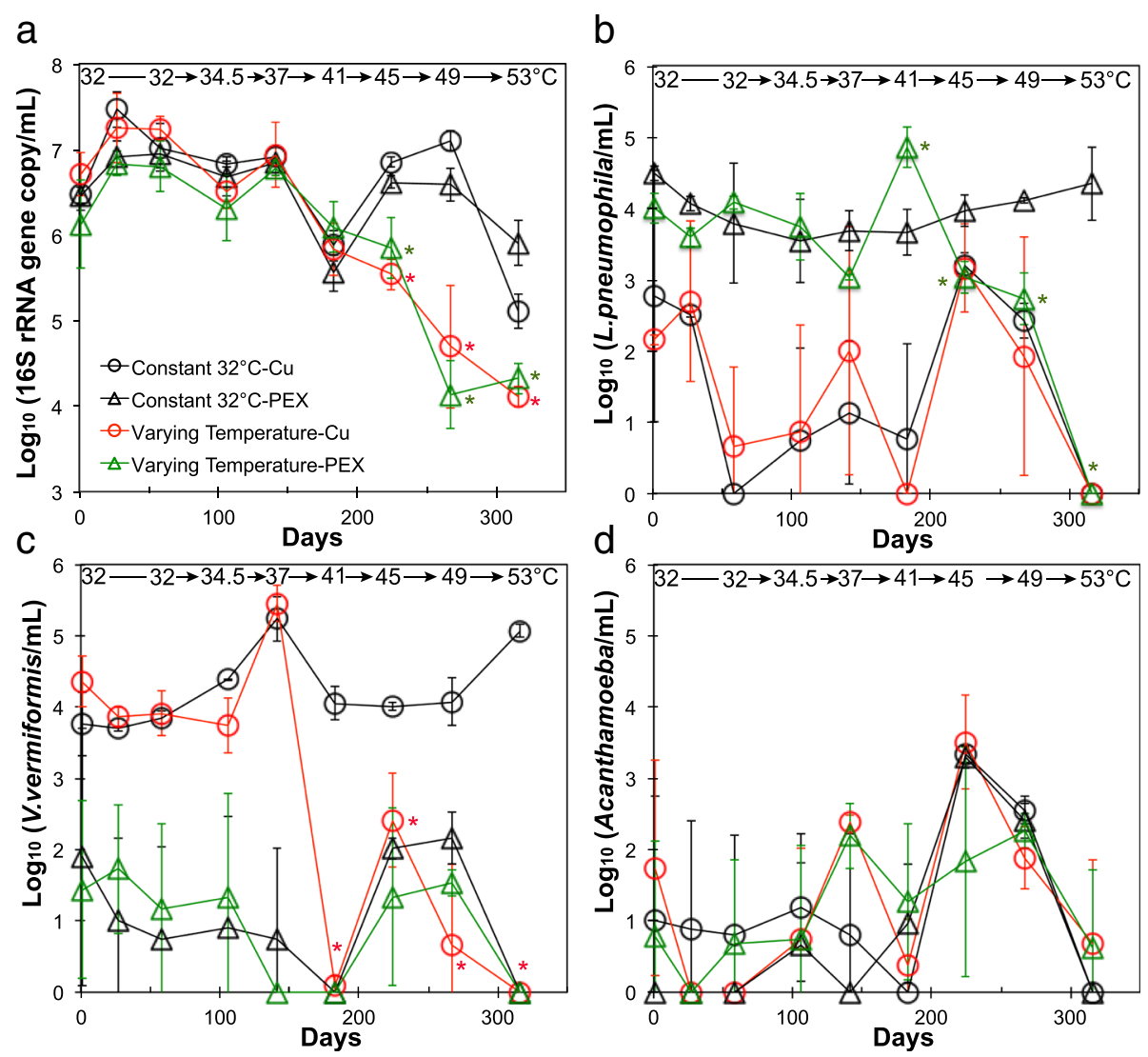

Fig. 1 Effect of temperature and pipe material on gene copy numbers of total bacteria (a), L. pneumophila (b), V. vermiformis (c), and Acanthamoeba (d) in SWHs dosed with $700 \mu \mathrm{g} / \mathrm{L} \mathrm{AOC}$ in the influent. All microbial numbers are $\log _{10}$-transformed gene copies/mL. SWHs with copper (circle) or PEX (triangle) pipe section were incubated constantly at $32^{\circ} \mathrm{C}$ (black) or at increasing temperatures from 32 to $53{ }^{\circ} \mathrm{C}$ (red for copper, green for PEX) from day 1 to day 316. Error bars are standard deviations of triplicate SWHs

a negative correlation was observed for PEX pipe at $53^{\circ}$ $\mathrm{C}(\rho=-0.66, p<0.01)$.

\section{L. pneumophila and amoebae gene markers}

Both pipe material and temperature significantly affected L. pneumophila and $V$. vermiformis gene copy numbers (hereafter "numbers") (Fig. 2a). Positive correlations between individual microorganisms and supplemented AOC were only occasionally found (Fig. 2b), primarily driven by the highest dose(s) of AOC.

The effect of pipe material was best illustrated in the first three samplings, before increasing the temperature, and the control SWHs at $32{ }^{\circ} \mathrm{C}$ (Fig. 1). SWHs with PEX pipe had consistently higher numbers $\left(2.5 \log _{10}\right)$ of $L$. pneumophila and lower numbers $\left(3.1 \log _{10}\right)$ of $V$. vermiformis compared to SWHs with copper pipe.

Temperature influenced L. pneumophila in SWHs with PEX (Fig. 1b), where numbers significantly increased and peaked at $41{ }^{\circ} \mathrm{C}$, followed by a drop at 45 and $49{ }^{\circ} \mathrm{C}$, and a further drop to below-detection at $53{ }^{\circ} \mathrm{C}(p<0.05$ in all cases relative to the $32{ }^{\circ} \mathrm{C}$ control). The relative abundance of $L$. pneumophila among total bacteria, estimated as the ratio of mip to $16 \mathrm{~S}$ rRNA gene copy numbers, peaked between 41 and $49^{\circ} \mathrm{C}$ (Fig. 3c). Similarly, temperature influenced $V$. vermiformis in SWHs with copper (Fig. 1c). $V$. vermiformis numbers decreased significantly to a level either below detection or $2-\log _{10}$ less than control reactors when the temperature was $\geq 41{ }^{\circ} \mathrm{C}$. When numbers were low, impacts of material on Acanthamoeba (Fig. 1d) or temperature on L. pneumophila (in copper SWHs) and $V$. vermiformis (in PEX SWHs) could not be discerned.

\section{Copper ion $\left(\mathrm{Cu}^{2+}\right)$ dosing}

In a separate set of SWHs, increasing $\mathrm{Cu}^{2+}$ dose from $5 \mu \mathrm{g} / \mathrm{L}$ up to $1000 \mu \mathrm{g} / \mathrm{L}$ with time showed no effect on total bacterial numbers, but resulted in a significant decrease in the L. pneumophila numbers, both in terms of gene copies and cultivable bacteria (CFU/mL) (Fig. 4). $\mathrm{Cu}^{2+}$ dosing higher than $30 \mu \mathrm{g} / \mathrm{L}$ did not further reduce L. pneumophila gene copy numbers, but did reduce the cultivable number of $L$. pneumophila. There was no observed effect of $\mathrm{Cu}^{2+}$ dosing on Acanthamoeba numbers (Additional file 1: Fig. S3). 


\section{a}

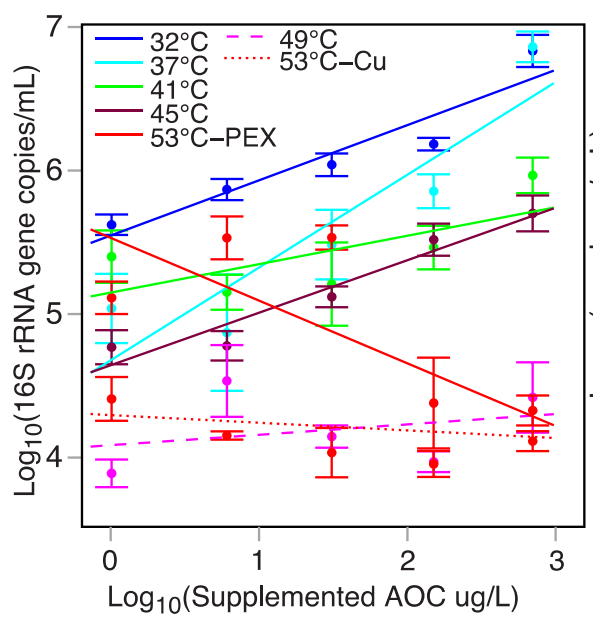

b

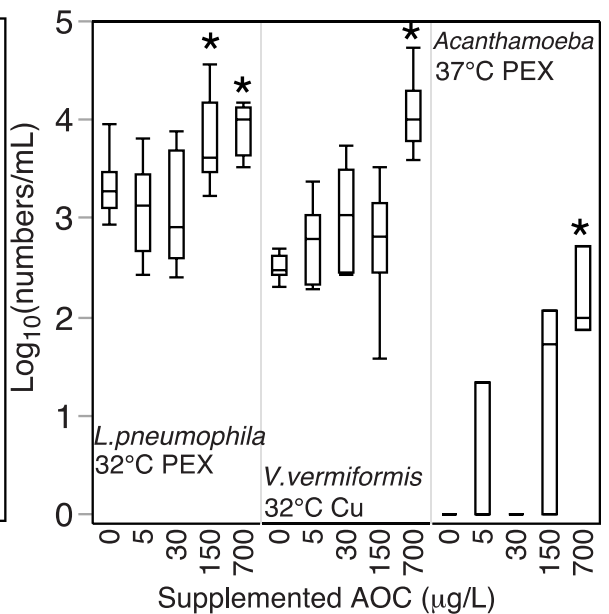

Fig. 2 Effect of dosed assimilable organic carbon (AOC) on gene copy numbers. a Correlations between the numbers of total bacteria and dosed AOC level. Linear regression lines are color-coded according to temperature as indicated. Means and standard errors from replicated SWHs are shown ( $n=6$ for combined pipe material data at $32-49^{\circ} \mathrm{C}, n=3$ for $53^{\circ} \mathrm{C}$, with each pipe material plotted individually). b Distribution of gene copy numbers of specific microbes of interest under temperature/pipe conditions where a significant effect of AOC supplementation was noted. For each boxplot, $n=9$ for $32^{\circ} \mathrm{C}$ and $n=3$ for $37^{\circ} \mathrm{C}$. Asterisk indicates significant difference compared to lower AOC levels according to post hoc ANOVA test

\section{Microbiota composition}

Each sample was rarefied to 12,430 sequences, and an NMDS plot was generated based on pair-wise Bray-Curtis dissimilarities (Fig. 5). The cold tap water influent samples consistently clustered separately from the SWH samples, illustrating a distinct hot water microbiota. When the temperature was $\leq$ $41{ }^{\circ} \mathrm{C}$, pipe material was the dominant factor shaping the composition of the microbiota. At 45 and
$49{ }^{\circ} \mathrm{C}$, the composition of the microbial communities converged, regardless of the pipe material, but at $53{ }^{\circ} \mathrm{C}$ the effects of PEX and copper were again apparent with greater variation among replicates. Samples from SWHs maintained constantly at $32{ }^{\circ} \mathrm{C}$ through time remained clustered, providing confirmation that the observed shifts in microbiota composition were driven by temperature rather than temporal variation.
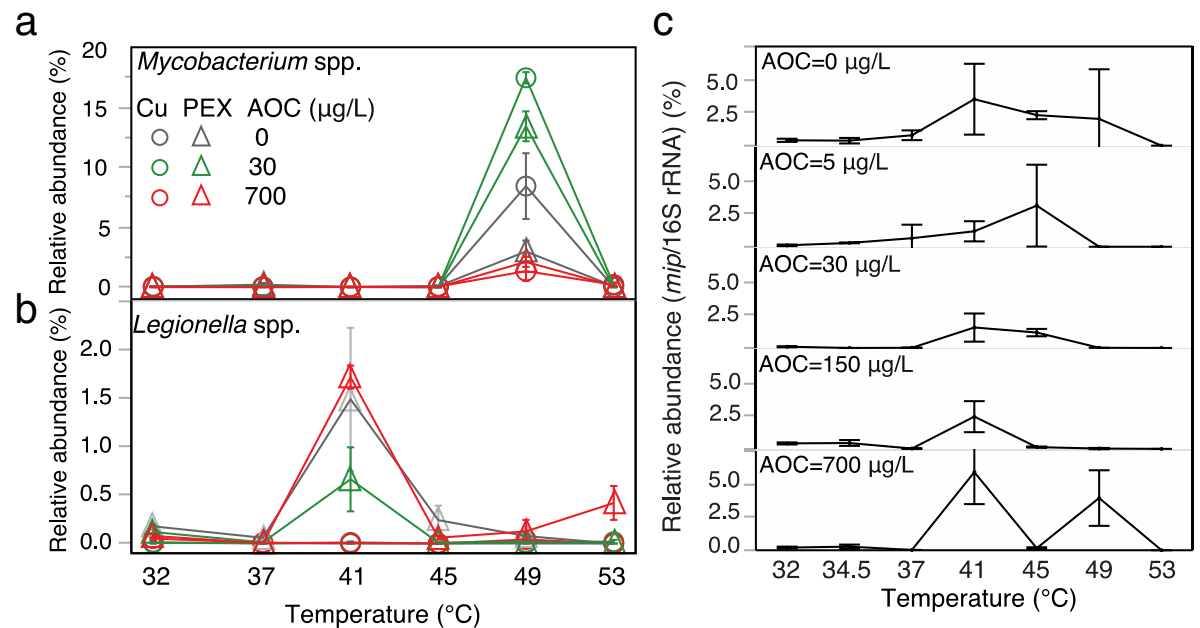

Fig. 3 Effect of various factors on relative abundances of potential opportunistic pathogens. Changes in the relative abundance of a Mycobacterium spp. and $\mathbf{b}$ Legionella spp. with temperature based on Illumina sequencing. $\mathbf{c}$ Relative abundance of L. pneumophila based on qPCR (mip gene copies/16S rRNA gene copies) for PEX condition only. Water supplemented with 0-700 $\mu \mathrm{g} / \mathrm{L}$ AOC were fed to SWHs and incubated at increasing temperatures $\left(32-53^{\circ} \mathrm{C}\right)$. Circles and triangles represent SWHs with copper and PEX pipe sections, respectively. Error bars represent standard errors of triplicate SWHs 

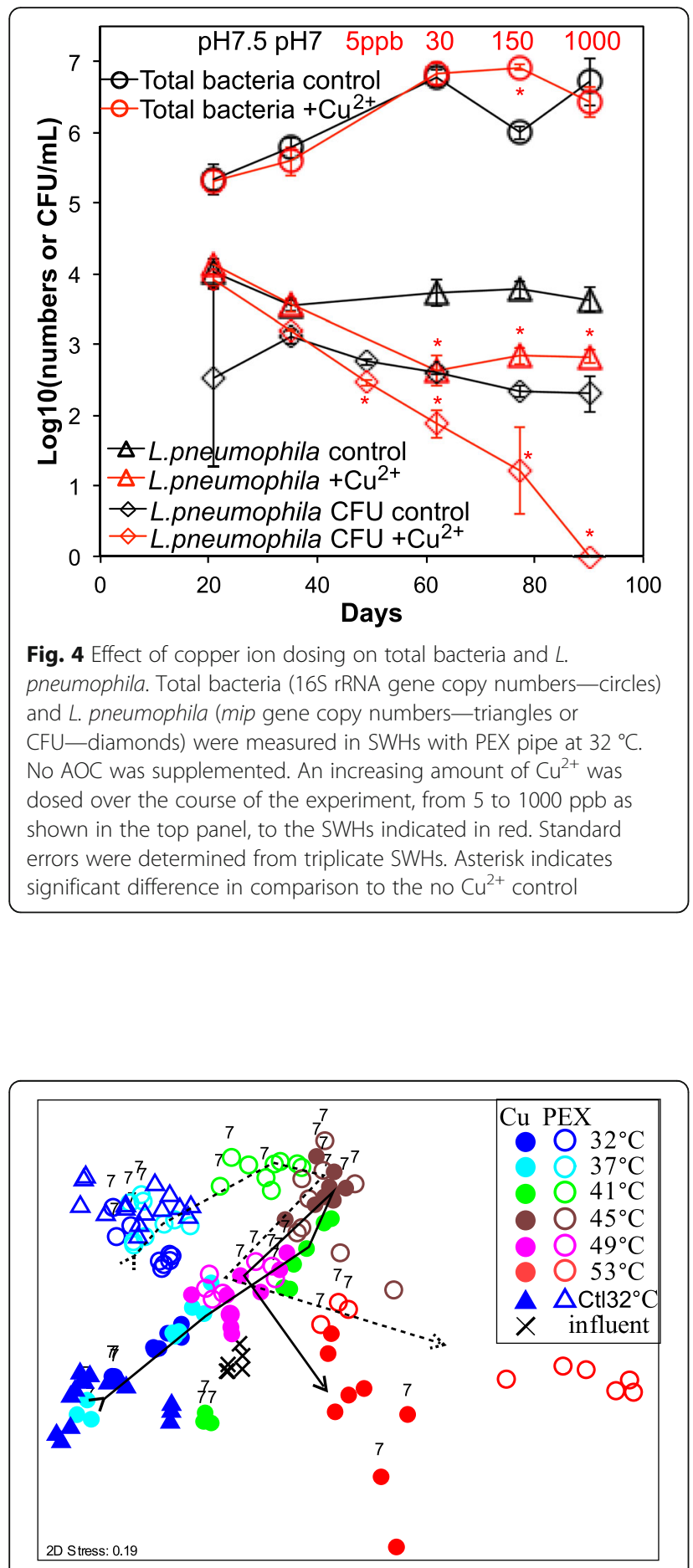

Fig. 5 NMDS plot illustrating the overall dissimilarities among hot water microbiota. Circles represent SWHs with copper (solid) or PEX (open) pipe incubated at varying temperatures (blue, $32^{\circ} \mathrm{C}$; cyan, $37^{\circ} \mathrm{C}$; green, $41^{\circ} \mathrm{C}$; brown, $45^{\circ} \mathrm{C}$; magenta, $49^{\circ} \mathrm{C}$; red, $53^{\circ} \mathrm{C}$ ) in comparison the control set maintained at $32^{\circ} \mathrm{C}$ (triangles, $\mathrm{Ctl} 32^{\circ} \mathrm{C}$ ). Cross symbols represent influent water (after GAC filtration) at the time of $37^{\circ} \mathrm{C}$ incubation. Labels of "7" above a symbol indicate $700 \mu \mathrm{g} / \mathrm{L}$ dosed AOC, while non-labeled conditions represent 0 and $30 \mu \mathrm{g} / \mathrm{L}$ dosed AOC. The trajectory lines (solid — copper; dashed_-PEX) indicate the trend of microbiota changing with increasing temperatures
According to Adonis analysis (Table 1), temperature was the primary driver of the majority of variation (43\%) in the microbiota composition, while pipe material and AOC were associated with a significant, but smaller impact (explaining 7 and $4 \%$ of the variation, respectively). The effect of pipe material surpassed that of dosed AOC level at temperatures $\leq$ $45{ }^{\circ} \mathrm{C}$ by other analyses as well (ANOSIM, $p<0.01$, Additional file 1: Table S1). The effect of dosed AOC was observed primarily among comparisons within the same temperature/pipe material. The addition of $30 \mu \mathrm{g} / \mathrm{L}$ AOC was significant only at the two lowest temperatures (32 and $37{ }^{\circ} \mathrm{C}, p<0.05$ ). Dosing of $700 \mu \mathrm{g} / \mathrm{L}$ AOC resulted in a significant effect, with a distinct microbiota composition from that of lower AOC levels at each temperature $\left(32-53{ }^{\circ} \mathrm{C}, p<0.05\right)$ with the same pipe material (Additional file 1: Table S1).

The two most dominant phyla switched from Proteobacteria (57\%) and Bacteroidetes (37\%) at $32{ }^{\circ} \mathrm{C}$ to Firmicutes (54\%) and Proteobacteria (25\%) at $53{ }^{\circ} \mathrm{C}$ (Fig. 6a). Actinobacteria populations were also enriched at higher temperatures $\left(49\right.$ and $\left.53{ }^{\circ} \mathrm{C}\right)$.

\section{Microbial diversity}

Shannon diversity decreased as temperature increased from 41 to $45{ }^{\circ} \mathrm{C}$, but then significantly increased (1.2-1.7 times) at 49 and $53{ }^{\circ} \mathrm{C}$, regardless of pipe material (compared to temporal changes observed in the control SWHs, Fig. 6b). Together with increased diversity (Shannon index) at 49 and $53{ }^{\circ} \mathrm{C}$, there wasmore evenness (1.3-1.8 times for both copper and PEX) and lower richness (0.4-0.5 times for PEX only). SWHs with PEX usually had higher Shannon diversity than copper. The effects of dosed AOC level on Shannon diversity varied with temperature (Additional file 1: Fig. S4). The highest AOC level $(700 \mu \mathrm{g} / \mathrm{L})$ resulted in a lower Shannon index, with

Table 1 Relative impacts of the three factors and their interactions on hot water microbiota. Results shown as analysis of similarity (ANOSIM) global R statistics

\begin{tabular}{lll}
\hline Factors & $\begin{array}{l}\text { Explained variations in } \\
\text { microbiota }\end{array}$ & $\begin{array}{l}\text { Overarching factor test } \\
\text { ANOSIM }\end{array}$ \\
\hline Temperature (T) & $43 \%^{*}$ & $R=0.63^{*}$ \\
Pipe material (M) & $7 \%^{*}$ & $R=0.16^{*}$ \\
AOC (C) & $4 \%^{*}$ & $R=0.002(p>0.05)$ \\
$\mathrm{T} \times \mathrm{M}$ & $14 \%^{*}$ & - \\
$\mathrm{T} \times \mathrm{C}$ & $12 \%^{*}$ & - \\
$\mathrm{C} \times \mathrm{M}$ & $3 \%^{*}$ & - \\
$\mathrm{T} \times \mathrm{C} \times \mathrm{M}$ & $7 \%^{*}$ & - \\
Residuals & $11 \%$ & - \\
\hline
\end{tabular}

*Indicates $p$ value $<0.001$ 

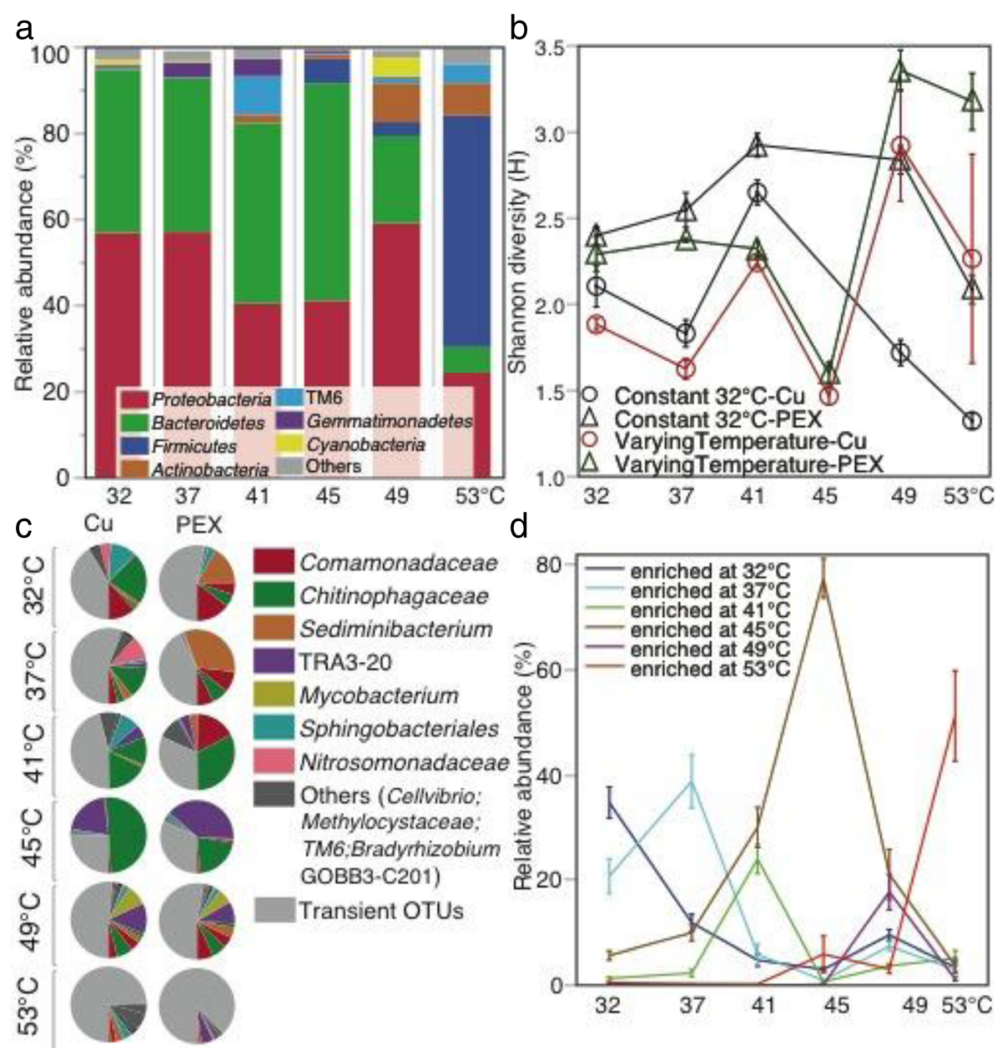

Fig. 6 Effects of temperature and pipe material on microbiota composition and diversity. a Phylum composition, (b) Shannon diversity, (c) 14 persistent OTUs at all temperatures for both pipe materials, and (d) OTUs selectively enriched with temperature. OTUs being undetected in any temperature or pipe material are grouped as "Transient OTUs". Standard errors were determined from triplicate SWHs (b and $\mathbf{d}$ panels). Each plotted line in panel $\mathbf{d}$ represents three to five OTUs enriched at each temperature (see Additional file 1: Table S2 for details)

few exceptions (copper and PEX at $41-45{ }^{\circ} \mathrm{C}$, PEX at $\left.53{ }^{\circ} \mathrm{C}\right)$.

\section{OTUs persisting across temperatures and pipe materials} Some OTUs persisted from warm $\left(32{ }^{\circ} \mathrm{C}\right)$ to hot $\left(53{ }^{\circ} \mathrm{C}\right)$ conditions, indicating their resistance or tolerance to this substantial temperature shift. A total of 14 OTUs were detected across all temperatures in both copper and PEX (Fig. 6c). Although their relative abundances shifted with temperature and pipe material, together, these persistent OTUs accounted for $\sim 50 \%$ of the microbiota at all temperatures except $53{ }^{\circ} \mathrm{C}\left(<20 \%\right.$ at $\left.53{ }^{\circ} \mathrm{C}\right)$.

\section{OTUs selectively enriched at various temperatures}

Some OTUs were enriched mainly at a specific temperature. Each set of 4-7 OTUs was identified to have significantly higher abundance at one temperature than all other temperatures, across both pipe materials and all AOC levels (Fig. 6d, Additional file 1: Table S2). The selectively enriched OTUs at 41,49 , or $53{ }^{\circ} \mathrm{C}$ were highly specific to temperature, displaying high abundance $(18-78 \%)$ at the corresponding temperature, but becoming "rare" (total abundance $<5 \%$ ) at all other temperatures.

OTUs selectively enriched by different pipe materials Based on PCoA analysis of all samples at $32{ }^{\circ} \mathrm{C}$ (Fig. 7), over a dozen OTUs were identified as enriched by either PEX (positive correlation with PCoA1 axis) or copper (negative correlation with PCoA1 axis). Additionally, five or six of these OTUs were enriched in PEX or copper across all lower temperatures $\left(32-41{ }^{\circ} \mathrm{C}\right)$, accounting for $30-40 \%$ of the community in the corresponding pipe material and $<5 \%$ in the other pipe material.

\section{Genera containing pathogens}

Several genera were of particular interest because they potentially contain OPs. Temperature was the most influential factor to the relative abundances of Mycobacteria, Pseudomonas and Stenotrophomonas, peaking at 49,53 , and $53{ }^{\circ} \mathrm{C}$, respectively, regardless of pipe material (Fig. 3a, Additional file 1: Fig. S5). Dosed AOC level up to $30 \mu \mathrm{g} / \mathrm{L}$ was associated with an increase in the relative abundance of Mycobacteria. Among the four OP-containing genera tracked in this study, only the relative abundance of 


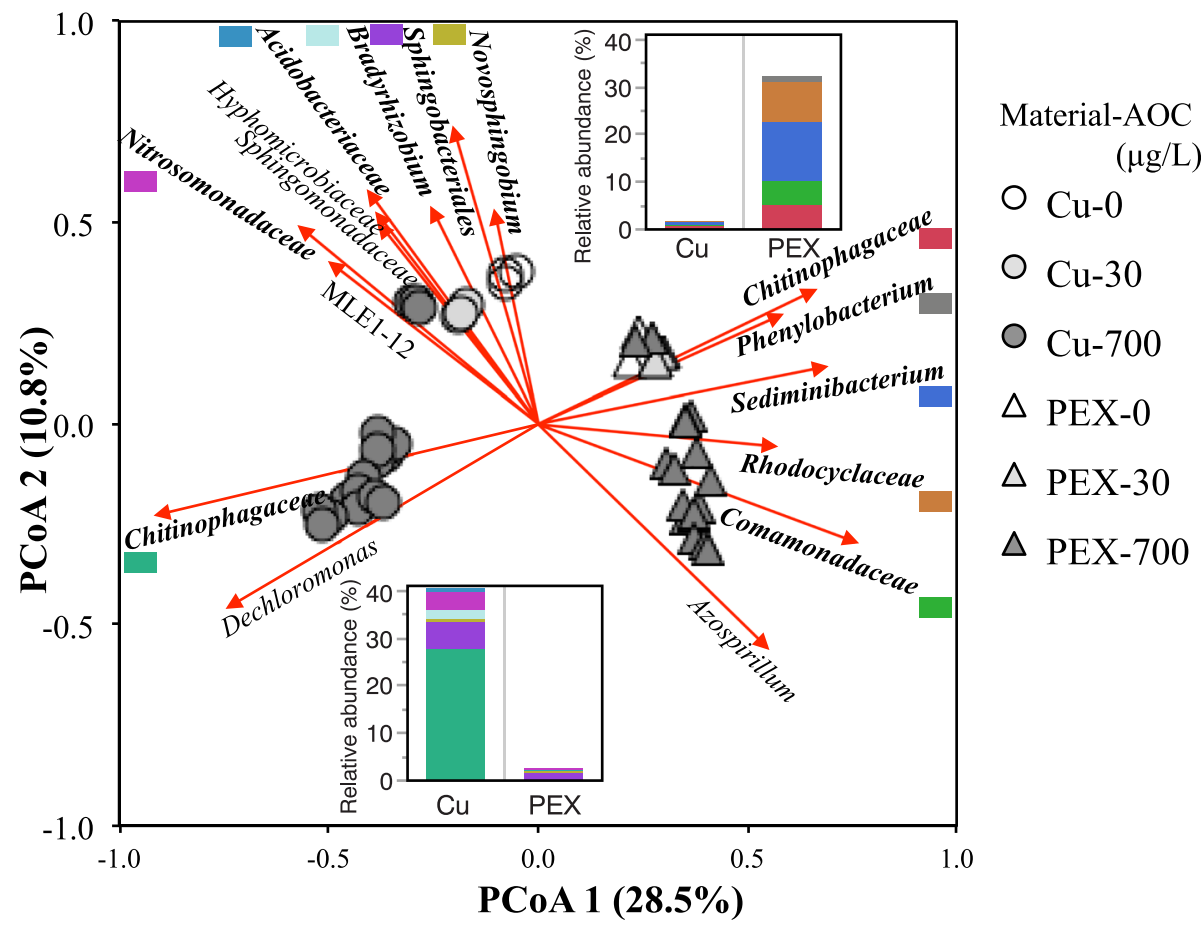

Fig. 7 Impact of pipe material on hot water microbiota illustrated using PCOA plot of SWHs with copper (circles) or PEX (triangles) pipe sections supplemented with 0 (white), 20 (light gray), or 700 (dark gray) microgram per liter AOC and incubated at $32^{\circ} \mathrm{C}$. The most abundant OTUs significantly correlated with both axes are shown as the arrows and labeled with their best-known taxonomy identification. In bold are OTUs significantly enriched in one pipe material at all lower temperatures $\left(32-41^{\circ} \mathrm{C}\right)$. Embedded figures show the relative abundance of copper (lower) and PEX (upper) enriched OTUs in SWHs at $32{ }^{\circ} \mathrm{C}$

Legionella was significantly influenced by pipe material (Fig. 3b), remaining low in SWHs with copper $(<0.2 \%)$, but peaking at $41{ }^{\circ} \mathrm{C}$ with a relative abundance of $>1.5 \%$ of the total microbial composition in the PEX pipe condition.

\section{Variance among replicates}

Variance in microbiota composition among SWH replicates (estimated as pairwise Bray-Curtis dissimilarities) increased markedly at 49 and $53{ }^{\circ} \mathrm{C}$ in SWHs with copper pipe, but remained relatively stable in SWHs with PEX over the range of temperatures (Additional file 1: Fig. S6). Dissimilarities among replicates were higher in PEX $(\sim 30 \%)$ than copper $(\sim 12 \%)$ among SWHs at lower temperatures $\left(\leqq 45{ }^{\circ} \mathrm{C}\right)$, with most dissimilarity among replicates attributed to the $700 \mu \mathrm{g} / \mathrm{L}$ AOC condition.

\section{Comparison of microbiota and qPCR profiling}

Absolute abundance of Legionella spp. could be roughly calculated by multiplying the relative abundance of the genus from Illumina sequencing data with the absolute number of $16 \mathrm{~S}$ rRNA gene copies determined with qPCR. Such methods have been employed previously $[34,44]$. When comparing results from this method with the absolute number of $L$. pneumophila determined with qPCR, highly similar trends were produced (Fig. 8), with the absolute numbers of L. pneumophila and Legionella spp. both peaking at $41{ }^{\circ} \mathrm{C}$.

We further compared microbiota and qPCR analyses by correlating the relative abundances of $L$. pneumophila calculated from qPCR with the relative abundances of the 100 most dominant OTUs identified by the amplicon sequencing. The strongest positive correlation with L. pneumophila numbers was a Legionella OTU (OTU69) $(\rho=0.47)$. The second highest correlation was with an OTU with a high sequence similarity to Methylophilus ( $\rho=0.37$ ), which is a known endosymbiont of Acanthamoeba [45].

\section{Discussion}

Temperature, material, and AOC all affected hot water microbial composition and L. pneumophila occurrence. Here, we systematically discuss the relative importance of each factor and interactive effects among them.

\section{Temperature}

While temperature control is an established method of preventing OP regrowth [10], recommendations for water heater settings vary due to conflicting priorities and goals [11-14]. In this study, a temperature of $53{ }^{\circ} \mathrm{C}$ uniformly reduced $L$. pneumophila and $V$. vermiformis (a 


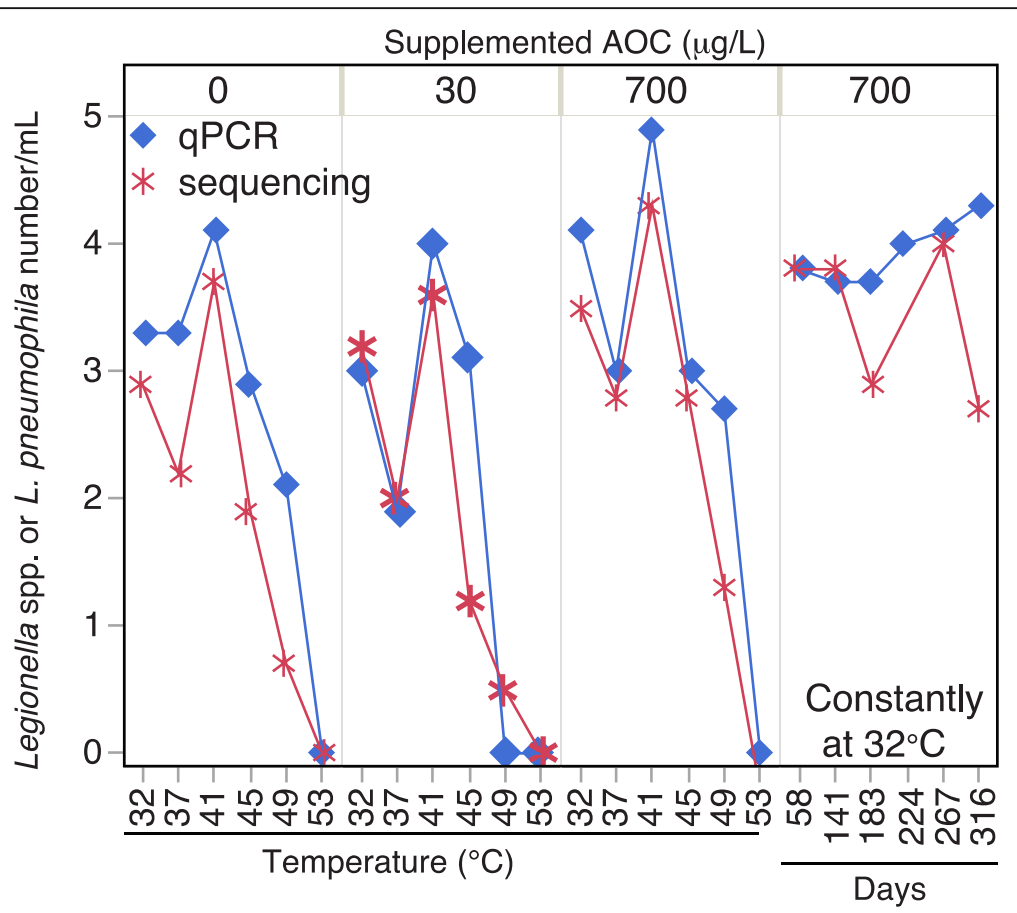

Fig. 8 Absolute number of L. pneumophila quantified by qPCR in comparison to the number of Legionella spp. determined by Illumina sequencing. To determine absolute number of Legionella spp. using Illumina sequencing information, the relative abundance (\%) of OTUs belonging to the genera Legionella spp. was multiplied with the number of 165 gene copies quantified qPCR

key host for L. pneumophila) to below detection, regardless of AOC or pipe material conditions (Fig. 1b, c). This supports the concept of temperature as a diagnostic of risk of OP colonization [10]. It also suggests that $55^{\circ} \mathrm{C}$, a temperature considerably lower than the standard set point $60{ }^{\circ} \mathrm{C}$, can technically be effective if achieved homogeneously in the system, as was the case in these SWHs. However, water temperature in realistic water heaters and hot water distribution pipes is typically lower than the set point due to cooling in distal pipes or mixing with cold water $[8,46]$. In a recent pilot-scale simulation, L. pneumophila remained detectable at the tap and in the recirculating line even when the water heater was set at $58{ }^{\circ} \mathrm{C}$ [8].

Based on OP-containing genera identified by amplicon sequencing, mid-range temperatures $\left(41-49{ }^{\circ} \mathrm{C}\right.$ ) could be more problematic than the assumed "worst-case scenario" of $32{ }^{\circ} \mathrm{C}$. For example, Mycobacterium spp., while consistently detected at all temperatures in both pipe materials, peaked at $49{ }^{\circ} \mathrm{C}$ (Fig. 3a). L. pneumophila numbers peaked in PEX reactors when maintained at $41{ }^{\circ} \mathrm{C}$ (Fig. 1b), matching a spike in calculated relative abundance and both relative and calculated absolute abundance of Legionella spp. based on amplicon sequencing (Figs. 3 and 8). The peak concentrations of L. pneumophila in this study (5.2 $\log _{10}$ mip gene copies $/ \mathrm{mL}$ ) may even surpass the critical threshold for $L$. pneumophila infection of $10^{7} \mathrm{CFU} / \mathrm{L}$, which was identified in a quantitative microbial risk assessment model [47].
While temperature was the most influential factor inducing differences in microbiota structure, there were 14 persistent OTUs that dominated at most temperatures for both materials (Fig. 6c). These OTUs include some implicated in regrowth during stagnation (Comamonadaceae, Bradyrhizobium) [48], some commonly identified in drinking water biofilms (Mycobacterium and Sphingobacteriales) [34], some likely involved in nitrogen cycling (Nitrosomonadaceae) [49] and some potential methanotrophs known to degrade chlorine byproducts (Methylocystaceae) [50]. The former two are likely related to the imposed hydraulic cycle of 2-3 days between water changes and constant seeding from mature SWH biofilms, a phenomenon previously observed in other systems [16]. The latter two may indicate that the breakdown of disinfection byproducts continues to influence SWHs, even though the influent water was breakpoint chlorinated.

The microbiota shift at $53{ }^{\circ} \mathrm{C}$ was mostly attributed to Firmicutes. While Firmicutes were previously associated with adoption of a new chloramine disinfection system in a hospital [51], in this study, it is their thermophilic nature that likely provided them a selective advantage [52]. Actinobacteria were also enriched at this temperature, consistent with the selective advantage of high GC content and Gram-positive characteristics at high temperature.

Interestingly, the community changes occurring at each temperature increase could be largely accounted 
for by just a few OTUs that were enriched at individual temperatures (Fig. 6d). These OTUs are particularly interesting at $41{ }^{\circ} \mathrm{C}$, when $L$. pneumophila peaked in PEX reactors and the communities with both materials began to converge. Novosphingobium, an aromatic carbon degrader [53], and Caulobacter were favored. Caulobacter was previously associated with shower hose biofilms that formed under similar conditions $\left(41{ }^{\circ} \mathrm{C}\right.$ with 24 -h stagnation) and consistently contained Legionella [34]. Together with the previously mentioned Methylophilus, these OTUs may be indicators for Legionella issues.

This study clearly indicates that temperature will induce shifts in hot water microbial structure, even with differences as little as $4{ }^{\circ} \mathrm{C}$. While previous studies have shown wide-scale differences between hot and cold water microbiota [16], to the authors' knowledge, this is the first study to examine such fine-scale adaptation to temperature under conditions representative of building plumbing. The fine-scale temperature adjustment approach selected here allowed the microbial community to gradually adapt and helped to identify threshold temperatures likely to be effective for opportunistic pathogen control under various conditions. Such fine-scale adjustments may also be made in the real world in seeking to address concerns such as energy, scalding, or cost. It is important to note, however, that a dramatic "heatshock" type temperature adjustment would likely have resulted in microbial community structures distinct from those observed here. While incremental shifts may allow bacteria to build up resistance to higher temperature, sudden increase from 32 to $53{ }^{\circ} \mathrm{C}$ would trigger a heatshock response [54].

\section{Pipe material}

Copper pipe had no measureable effect on total bacterial numbers in our long-term aged pipe study (Fig. 1a). Although copper pipes may retard initial biofilm formation relative to plastic pipes [22], often, studies are conducted using a new pipe material, where the effects of carbon leaching from plastics and $\mathrm{Cu}^{+2}$ from copper pipes are greatest. This experiment was conducted with pipes that were experimentally operational and aged for $>3$ years, greatly exceeding prior studies of 30 days [55], 1 year $[16,18]$, and 2 years [21]. Although a general toxicity of copper on total bacterial numbers was not observed, aged copper pipe exerted selective pressure that benefitted some microorganisms over others, as illustrated by the microbiota composition (Fig. 7) and response of specific OPs and organisms of interest.

There is some evidence that copper pipe can be beneficial for some free-living amoeba (FLA) hosts for $L$. pneumophila [56]. In this study, SWHs with aged copper pipes had higher concentrations of $V$. vermiformis than PEX reactors at low temperatures (Fig. 1b), while
Acanthamoeba did not respond to $\mathrm{Cu}^{+2}$ dosing (Additional file 1: Fig. S3). Although co-occurrence of FLA and L. pneumophila has been reported [57], specific FLA and L. pneumophila may respond differently to stresses like temperature [58], potentially explaining the discrepancy in $L$. pneumophila versus $V$. vermiformis response in this study. Additionally, although potential copper pipe toxicity towards Mycobacterium was observed in a prior building survey [16], Mycobacterium was persistent on both materials in this study.

Below $45{ }^{\circ} \mathrm{C}$, copper pipe consistently suppressed $L$. pneumophila numbers compared to PEX, even after 2.5 years of conditioning and operation of the present experiment for over a year (Fig. 1b). The $\mathrm{Cu}^{+2}$ dosing study made it possible to further examine the selective pressure. A concentration as low as $5-30 \mu \mathrm{g} / \mathrm{L}$ effectively inhibited L. pneumophila at $32{ }^{\circ} \mathrm{C}$ (Fig. 4), indicating that the lower L. pneumophila numbers in SWHs with aged copper pipe than PEX pipe at day 1 may be due to its sensitivity to $\mathrm{Cu}^{+2}$ released from copper pipe during the acclimation period.

At lower temperatures, there was a clear distinction in the microbiota structure associated with copper versus PEX (Fig. 7). The OTUs associated with PEX represented a variety of ecological niches consistent with the leaching of diverse organic carbon from the plastic [19, 23]. For example, Phenylobacterium has a specific metabolism associated with herbicides and complex carbon [59] and Sediminibacterium was previously associated with biofilms on PVC-P [34]. The wide range of carbon niches could also account for the higher Shannon diversity observed in PEX SWHs. Previously, a higher diversity was also observed in biofilms on plastic than on copper [56].

The OTUs specific to the copper condition were associated with adaptive metabolism and resistance to harsh environments, likely reflecting the toxicity of the copper pipes and lowered carbon availability compared to the PEX condition. For example, some are known for tolerance to acidic conditions (Acidobacteriaceae) [60] and preference for low organic carbon levels (Hyphomicrobiaceae) [61]. Pseudomonas was also persistent in $\mathrm{Cu}$ SWHs, and the opportunistic pathogen, $P$. aeruginosa, has previously demonstrated copper resistance [62]. At higher temperatures, the distinction between materials became less obvious.

Prior studies have yielded conflicting conclusions with respect to the relative effects of copper versus plastic (PEX, PVC, C-PVC) pipes on levels of L. pneumophila and other organisms $[16,18,21,22,55,63,64]$. However, since temperature can alter the water chemistry (e.g., $\mathrm{pH}$ ) and overall tendency towards dissolution of copper ions from pipes [65], it is critical to consider both water chemistry and physiochemical parameters when determining the effectiveness of copper pipe in controlling $L$. 
pneumophila. We hypothesize that the influence of pipe material is highly dependent on water temperature, which governs both leaching of organic carbon from plastics and copper dissolution chemistry.

In this study, higher temperature decreased the dissolution of total copper from the pipe (Additional file 1: Fig. S7), and further, this copper also likely had decreased solubility [66]. Thus, as one selective pressure was increased (temperature), another selective pressure was relieved (copper), perhaps accounting for the converging communities and similar response of $L$. pneumophila between pipe materials at these temperatures. SWHs with aged copper pipe at high temperatures had a noticeable increase in microbiota dissimilarity among replicates (Additional file 1: Fig. S6), possibly because new niches opened up by reduced copper pressure were quickly occupied by different organisms among the replicates.

At $53{ }^{\circ} \mathrm{C}$, there was strong evidence of organic carbon leaching from the PEX pipes. The negative $\triangle T O C$ in PEX reactors at higher temperature indicated that leaching of organic carbon from the pipe exceeded the organic carbon consumed by microbes. Although the pipes were aged and carbon leaching tends to diminish over time, higher temperatures can still greatly increase the amount of TOC leaching from pipes [19]. There was also a strong shift in the microbiota structure at $53{ }^{\circ} \mathrm{C}$ in PEX reactors, especially when dosed AOC was low (0, $30 \mu \mathrm{g} / \mathrm{L}$ ) (Additional file 1: Fig. S8). The communities with little dosed $\operatorname{AOC}(0,30 \mu \mathrm{g} / \mathrm{L})$ likely adapted to utilize the newly dominant PEX-derived carbon source, while those with higher dosed AOC $(700 \mu \mathrm{g} / \mathrm{L})$ could continue the previous metabolic patterns utilizing dosed AOC.

\section{$\mathrm{AOC}$}

AOC has been extensively studied in water distribution main systems (from treatment plant or source to consumers), with reduction below 100 or $10 \mu \mathrm{g} / \mathrm{L} \mathrm{AOC} \mathrm{as-}$ sociated with effective control of regrowth, depending on other limiting factors [30-32]. However, these limits have not been validated for controlling regrowth within the hot water plumbing environment, where AOC can also be generated from pipes, especially when stagnation events greater than $6 \mathrm{~h}$ are common $[34,46]$. In this experiment, the incoming carbon concentration was first minimized via biologically active GAC filtration, in order to reduce the background TOC/AOC and exclude potential effects of seasonal AOC variations.

Increasing $\mathrm{AOC}$ levels resulted in more bacteria at temperatures $\leq 45{ }^{\circ} \mathrm{C}$, consistent with consumption of TOC and incorporation into biomass (Fig. 2a, Additional file 1: Figs. S1 and S2). However, in PEX reactors at $53{ }^{\circ} \mathrm{C}$, there was a negative correlation between dosed
AOC and 16S rRNA genes (Fig. 2a). With temperaturedependent leaching from pipes, local carbon production diminished the importance of the influent water, as has been previously observed with plastic pipes [34, 67].

Although other studies have found correlations between TOC and L. pneumophila in flowing hot [27] and cold water systems [68], in this study, only the highest levels of supplemented AOC corresponded to an increase in L. pneumophila or other organisms of interest, while high levels even seemed to suppress Mycobacteria. Thus, there may be a threshold at which AOC control is no longer effective for specific OPs, as suggested by Williams et al. [35]. Carbon production within the building (e.g., plastics leaching carbon) and specific preferences of potential pathogens may change the community response to increased carbon. For example, some organisms, like Mycobacteria and $P$, aeruginosa, may prefer a lower range of AOC because they can out-compete others for carbon in oligotrophic stagnant environments, as has been previously observed [34, 69]. Regardless, $L$. pneumophila and FLA are not directly dependent on carbon available in the water, especially under warm stagnant conditions, but rather derive largely secondary influences of carbon and broader microbiota as an intermediary [70, 71].

Finally, the low Shannon diversity and high dissimilarity among replicate SWHs in the $700 \mu \mathrm{g} / \mathrm{L}$ AOC condition may be related to the semi-batch nature of the reactors. A high concentration of easily assimilable organic carbon may select for fast-growing organisms that out-compete others for secondarily limiting nutrients (nitrogen, phosphorus), ultimately limiting diversity. Which bacteria dominate in semibatch growth reactor can vary considerably among replicates. A notable exception to this trend occurred in PEX reactors at $53{ }^{\circ} \mathrm{C}$, when carbon leaching introduced new carbon sources that were better utilized in the low carbon addition conditions.

\section{Conclusions}

This study brings to light the importance of interactive effects of temperature, pipe material, and AOC in shaping the microbiota composition and controlling OPs in building plumbing. While temperature was the strongest factor, increasing temperature did not linearly reduce concentrations of OPs or amoeba hosts, which peaked at temperatures $41-49{ }^{\circ} \mathrm{C}$. L. pneumophila and the two amoebae were reduced to below detection when the temperature was consistently maintained at $53{ }^{\circ} \mathrm{C}$. Temperature also mediated the leaching behavior of pipes, reducing the selectively inhibitive effect of copper pipes and increasing TOC release from plastic pipes. AOC correlated with total bacteria, but not with L. pneumophila. 


\section{Additional file}

Additional file 1: Fig. S1. Correlations between (A) influent TOC and (B) $\triangle T O C$ (TOCin-out) with supplemented AOC at 37 and $53^{\circ} \mathrm{C}$. Fig. S2. Linear correlation between total bacterial numbers and $\triangle T O C$ (TOCin-TOCout) in SWHs at $37^{\circ} \mathrm{C}$ (copper and PEX) and $53{ }^{\circ} \mathrm{C}$ (copper). Fig. S3. Impact of copper dosing on the number of Acanthamoeba spp. in SWHs with PEX pipe at $32{ }^{\circ} \mathrm{C}$. Fig. S4. Effect of supplemented AOC on Shannon diversity in SWHs with copper (red) or PEX (blue) pipe at each temperature $\left(32-53{ }^{\circ} \mathrm{C}\right.$ ). Fig. S5. Changes of relative abundance of (A) Pseudomonas spp. and (B) Stenotrophomonas spp. with temperature according to identification based on 165 rRNA gene amplicon sequencing. Fig. S6. Bray-Curtis dissimilarities among replicate SWHs. Fig. S7. Dissolved copper ions in SWH bulk water. Fig. S8. Effect of supplemented AOC and pipe material on phylum composition in hot water at each temperature $\left(32-53^{\circ} \mathrm{C}\right)$. Table S1. Impacts of pipe material and AOC on microbial composition at each temperature (shown as ANOSIM global R statistics). Table S2. Enriched OTUs at each temperature. (DOCX 1453 kb)

\section{Acknowledgements}

We acknowledge Brittany Flittner, Rachel Thomas, and Christine Pankow for significant contributions to reactor maintenance and lab work and Jeffery Parks for assistance with ICP measurements.

\section{Funding}

This study was funded by the Alfred P. Sloan Foundation Microbiology of the Built Environment Program, the U.S. National Science Foundation (CBET Awards No. 1033498 and 1336650), and the Institute for Critical Technology and Applied Science Center for Science and Engineering of the Exposome.

\section{Availability of data and materials}

The sequencing data generated in this study are available in the European Nucleotide Archive under project accession number PRJEB11665. All other data is available in this publication.

\section{Authors' contributions}

$\mathrm{CP}$ contributed to the study design, produced the data, and contributed to the data analysis and manuscript writing. DD analyzed the data, produced the figures, and contributed to the manuscript writing. ME and AP contributed to and oversaw the study design, data analysis, and manuscript writing and editing. All authors read and approved the final manuscript.

\section{Ethics approval and consent to participate}

Not applicable.

\section{Consent for publication}

Not applicable.

\section{Competing interests}

The authors declare that they have no competing interests.

\section{Publisher's Note}

Springer Nature remains neutral with regard to jurisdictional claims in published maps and institutional affiliations.

\section{Author details}

${ }^{1} V i a$ Department of Civil and Environmental Engineering, Virginia Tech, Blacksburg, Virginia 24061, USA. ²EAWAG, Swiss Federal Institute of Aquatic Science and Technology, Überlandstr 133, CH-8600 Duebendorf, Switzerland.

Received: 12 April 2017 Accepted: 20 September 2017 Published online: 04 October 2017

\section{References}

1. Brunkard JM, Ailes E, Roberts VA, Hill V, Hilborn ED, Craun GF, et al. Surveillance for waterborne disease outbreaks associated with drinking water-United States, 2007-2008. MMWR Surveill Summ. 2011;60:38-68. Available from: http://www.ncbi.nlm.nih.gov/pubmed/21937977.
2. Richards AM, Von Dwingelo JE, Price CT, Abu Kwaik Y. Cellular microbiology and molecular ecology of Legionella-amoeba interaction. Virulence Landes Bioscience. 2013;4:307-14. Available from: http://www.ncbi.nlm.nih.gov/ pubmed/23535283.

3. Shakoor S, Beg MA, Mahmood SF, Bandea R, Sriram R, Noman F, et al. Primary amebic meningoencephalitis caused by Naegleria fowleri, Karachi, Pakistan. Emerg Infect Dis. 2011;17:258-61. Centers for Disease Control and Prevention, Available from: http://www.ncbi.nlm.nih.gov/pubmed/21291600.

4. Yoder JS, Straif-Bourgeois S, Roy SL, Moore TA, Visvesvara GS, Ratard RC, et al. Primary amebic meningoencephalitis deaths associated with sinus irrigation using contaminated tap water. Clin Infect Dis. 2012;55:e79-85. Oxford University Press. Available from: http://www.ncbi.nlm.nih.gov/pubmed/22919000.

5. Qian Y, Meisler DM, Langston RHS, Jeng BH. Clinical experience with Acanthamoeba keratitis at the cole eye institute, 1999-2008. Cornea. 2010;29:1016-21. Available from: http://www.ncbi.nlm.nih.gov/pubmed/ 20539213

6. Dennis PJ. Legionella in the United Kingdom and water quality in buildings. ASHRAE Trans. 1991;1991:271-4.

7. Stout JE, Best MG, Yu VL. Susceptibility of members of the family Legionellaceae to thermal stress: implications for heat eradication methods in water distribution systems. Appl Environ Microbiol. 1986;52:396-9. American Society for Microbiology. Available from: http://www.ncbi.nlm.nih. gov/pubmed/3752999.

8. Rhoads WJ, Ji P, Pruden A, Edwards MA. Water heater temperature set point and water use patterns influence Legionella pneumophila and associated microorganisms at the tap. Microbiome. 2015;3:67. Available from: http:// www.pubmedcentral.nih.gov/articlerender.fcgi?artid=4666224\&tool= pmcentrez\&rendertype=abstract.

9. Wadowsky RM, Yee RB, Mezmar L, Wing EJ, Dowling JN. Hot water systems as sources of Legionella pneumophila in hospital and nonhospital plumbing fixtures. Appl Environ Microbiol. 1982:43:1104-10. American Society for Microbiology (ASM). Available from: http://www.ncbi.n/m.nih.gov/pubmed/7103477.

10. Bédard E, Fey S, Charron D, Lalancette C, Cantin P, Dolcé P, et al. Temperature diagnostic to identify high risk areas and optimize Legionella pneumophila surveillance in hot water distribution systems. Water Res. 2015;71:244-56.

11. CDC Injury Center. Burn Prevention | Child safety and injury prevention| CDC Injury Center. 2016 [cited 2016 Oct 2]. Available from: https://www.cdc. gov/safechild/burns/.

12. Energy Star Program, US Environmental Protection Agency, US Department of Energy. Start saving now: ENERGY STAR. 2016 [cited 2016 Oct 2]. Available from: https://www.energystar.gov/campaign/waysToSave?tagldList=FeaturedAdvice.

13. World Health Organization Europe. Policies to reduce unintentional injuries from falls, drowning, poisoning, fires and choking in children and adolescents. WHO Fact Sheet No. 2.6. 2007 [cited 2016 Oct 2]; Available from: http://www. euro.who.int/_data/assets/pdf_file/0004/97393/2.6.pdf?ua=1.

14. Lévesque B, Lavoie M, Joly J. Residential water heater temperature: 49 or 60 degrees Celsius? Can J Infect Dis. 2004;15:11-2. Pulsus Group. Available from: http://www.ncbi.nlm.nih.gov/pubmed/18159436.

15. Rhoads WJ, Pruden A, Edwards MA. Survey of green building water systems reveals elevated water age and water quality concerns. Environ Sci Water Res Technol. 2016;2:164-73. Royal Society of Chemistry. Available from: http://xlink.rsc.org/?DOI=C5EW00221D.

16. Inkinen J, Jayaprakash B, Santo Domingo JW, Keinänen-Toivola MM, Ryu H, Pitkänen T. Diversity of ribosomal 16S DNA- and RNA-based bacterial community in an office building drinking water system. J Appl Microbiol. 2016;120:1723-38. Available from: http://doi.wiley.com/10.1111/jam.13144.

17. National Research Council. Drinking water distribution systems. Washington, D.C.: National Academies Press; 2006. [cited 2016 Oct 2]. Available from: http://www.nap.edu/catalog/11728.

18. Inkinen J, Kaunisto T, Pursiainen A, Miettinen IT, Kusnetsov J, Riihinen K, et al. Drinking water quality and formation of biofilms in an office building during its first year of operation, a full scale study. Water Res. 2014;49:83-91.

19. Bucheli-Witschel M, Kötzsch S, Darr S, Widler R, Egli T. A new method to assess the influence of migration from polymeric materials on the biostability of drinking water. Water Res. 2012;46:4246-60.

20. Rogers J, Dowsett AB, Dennis PJ, Lee JV, Keevil CW. Influence of temperature and plumbing material selection on biofilm formation and growth of Legionella pneumophila in a model potable water system containing complex microbial flora. Appl Environ Microbiol. 1994:60: 1585-92. Available from: http://www.ncbi.nlm.nih.gov/pubmed/8017938. 
21. van der Kooij D, Veenendaal HR, Scheffer WJH. Biofilm formation and multiplication of Legionella in a model warm water system with pipes of copper, stainless steel and cross-linked polyethylene. Water Res. 2005;39: 2789-98. Available from: http://www.sciencedirect.com/science/article/pii/ S004313540500268X

22. Lehtola MJ, Miettinen IT, Keinänen MM, Kekki TK, Laine O, Hirvonen A, et al. Microbiology, chemistry and biofilm development in a pilot drinking water distribution system with copper and plastic pipes. Water Res. 2004:38:3769-79.

23. Skjevrak I, Due A, Gjerstad KO, Herikstad H. Volatile organic components migrating from plastic pipes (HDPE, PEX and PVC) into drinking water. Water Res. 2003:37:1912-20. Available from: http://www.sciencedirect.com/ science/article/pii/S0043135402005766.

24. Shih $\mathrm{H}-\mathrm{Y}$, Lin YE. Efficacy of copper-silver ionization in controlling biofilmand plankton-associated waterborne pathogens. Appl Environ Microbiol. 2010;76:2032-5. American Society for Microbiology (ASM). Available from: http://www.ncbi.nlm.nih.gov/pubmed/20080997. [cited 2016 Oct 2].

25. Lin YE, Stout JE, Yu VL. Controlling Legionella in hospital drinking water: an evidence-based review of disinfection methods. Infect Control Hosp Epidemiol. 2011;32:166-73. Cambridge University Press. Available from: http://www. journals.cambridge.org/abstract_S0195941700039898. [cited 2016 Oct 2].

26. Lehtola MJ, Miettinen IT, Lampola T, Hirvonen A, Vartiainen T, Martikainen PJ. Pipeline materials modify the effectiveness of disinfectants in drinking water distribution systems. Water Res. 2005;39:1962-71.

27. Leoni E, De Luca G, Legnani PP, Sacchetti R, Stampi S, Zanetti F. Legionella waterline colonization: detection of Legionella species in domestic, hotel and hospital hot water systems. J Appl Microbiol. 2005;98:373-9. Blackwell Science Ltd. Available from: http://doi.wiley.com/10.1111/j.1365-2672.2004. 02458.x. [cited 2016 Oct 2].

28. Bargellini A, Marchesi I, Righi E, Ferrari A, Cencetti S, Borella P, et al. Parameters predictive of Legionella contamination in hot water systems: association with trace elements and heterotrophic plate counts. Water Res. 2011;45:2315-21

29. Mathys W, Stanke J, Harmuth M, Junge-Mathys E. Occurrence of Legionella in hot water systems of single-family residences in suburbs of two German cities with special reference to solar and district heating. Int J Hyg Environ Health. 2008;211:179-85.

30. van der Kooij D. Assimilable organic carbon as an indicator of bacterial regrowth. J Am Water Works Assoc. 1992;84:57-65. American Water Works Association. Available from: http://www.jstor.org/stable/41293634.

31. Hammes F, Berger C, Köster O, Egli T. Assessing biological stability of drinking water without disinfectant residuals in a full-scale water supply system. J Water Supply Res Technol - Aqua. 2010;2010:59.

32. Volk CJ, LeChevallier MW. Assessing biodegradable organic matter (PDF). J Am Water Works Assoc AWWA. 2000;92:64-76.

33. Zhang $Y$, Edwards $M$, Pinto A, Love N, Camper A, Rahman M, et al. Effect of nitrification on corrosion in the distribution system. Denver: Water Research Foundation; 2010

34. Proctor CR, Gächter M, Kötzsch S, Rölli F, Sigrist R, Walser J-C, et al. Biofilms in shower hoses - choice of pipe material influences bacterial growth and communities. Environ. Sci. Water Res. Technol. 2016;2:670-82. The Royal Society of Chemistry. Available from: http://xlink.rsc.org/?DOl=C6EW00016A. [cited 2017 Apr 11].

35. Williams K, Pruden A, Falkinham JO, Edwards M, Williams K, Pruden A, et al. Relationship between organic carbon and opportunistic pathogens in simulated glass water heaters. Pathog (Basel, Switzerland). 2015;4:355-72. Multidisciplinary Digital Publishing Institute (MDPI). Available from: http:// www.ncbi.nlm.nih.gov/pubmed/26066310. [cited 2016 Dec 5].

36. Hammes FA, Egli T. New method for assimilable organic carbon determination using flow-cytometric enumeration and a natural microbial consortium as inoculum. Env Sci Technol. 2005;39:3289-94. 2005/06/02

37. Nazarian EJ, Bopp DJ, Saylors A, Limberger RJ, Musser KA. Design and implementation of a protocol for the detection of Legionella in clinical and environmental samples. Diagn Microbiol Infect Dis. 2008;62:125-32.

38. Kuiper MW, Valster RM, Wullings BA, Boonstra $H$, Smidt $H$, van der Kooij D. Quantitative detection of the free-living amoeba Hartmannella vermiformis in surface water by using real-time PCR. Appl Environ Microbiol. 2006;72: 5750-6. American Society for Microbiology. Available from: http://www.ncbi. nlm.nih.gov/pubmed/16957190 [cited 2016 Oct 2].

39. Rivière D, Szczebara FM, Berjeaud J-M, Frère J, Héchard Y. Development of a real-time PCR assay for quantification of Acanthamoeba trophozoites and cysts. J Microbiol Methods. 2006;64:78-83.
40. Suzuki MT, Taylor LT, DeLong EF. Quantitative analysis of small-subunit rRNA genes in mixed microbial populations via 5'-nuclease assays. Appl Environ Microbiol. 2000;66:4605-14. American Society for Microbiology. Available from: http://www.ncbi.n/m.nih.gov/pubmed/11055900. [cited 2016 Oct 2].

41. Wang H, Edwards M, Falkinham JO, Pruden A, et al. Appl Environ Microbiol. 2012;78:6285-94. American Society for Microbiology. Available from: http:// www.ncbi.nlm.nih.gov/pubmed/22752174. [cited 2016 Oct 2].

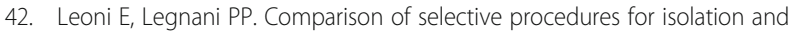
enumeration of Legionella species from hot water systems. J Appl Microbiol. 2001;90:27-33. Blackwell Science Ltd. Available from: http://doi. wiley.com/10.1046/j.1365-2672.2001.01178.x. [cited 2016 Oct 2].

43. Caporaso JG, Lauber CL, Walters WA, Berg-Lyons D, Huntley J, Fierer N, et al. Ultra-high-throughput microbial community analysis on the Illumina HiSeq and MiSeq platforms. ISME J. 2012;6:1621-4. Nature Publishing Group. Available from: http://www.nature.com/doifinder/10.1038/ismej.2012.8. [cited 2016 Oct 2].

44. Props R, Kerckhof F-M, Rubbens P, De Vrieze J, Hernandez Sanabria E, Waegeman $W$, et al. Absolute quantification of microbial taxon abundances. ISME J. 2016; Nature Publishing Group. Available from: http://www.nature. com/doifinder/10.1038/ismej.2016.117. [cited 2016 Dec 18]

45. Choi SH, Cho MK, Ahn SC, Lee JE, Lee JS, Kim D-H, et al. Endosymbionts of Acanthamoeba isolated from domestic tap water in Korea. Korean J Parasitol. 2009;47:337. Available from: http://www.ncbi.nlm.nih.gov/pubmed/ 19967080. [cited 2017 Aug 4].

46. Brazeau RH, Edwards MA. Role of hot water system design on factors influential to pathogen regrowth: temperature, chlorine residual, hydrogen evolution, and sediment. Env Eng Sci. 2013;30:617-27. 2013/10/31.

47. Schoen ME, Ashbolt NJ. An in-premise model for Legionella exposure during showering events. Water Res. 2011;45:5826-36. 2011/09/20

48. Proctor $C R$, Edwards MA, Pruden A. Microbial composition of purified waters and implications for regrowth control in municipal water systems. Environ. Sci. Water Res. Technol. 2015;1:882-92. The Royal Society of Chemistry. Available from: http://pubs.rsc.org/en/content/articlehtml/2015/ew/ c5ew00134j. [cited 2016 Jan 2].

49. Prosser II, Head IM, Stein LY. The family Nitrosomonadaceae, The Prokaryotes. Berlin: Springer Berlin Heidelberg; 2014. p. 901-18. Available from: http://link. springer.com/10.1007/978-3-642-30197-1_372. [cited 2016 Oct 16].

50. Huhe, Nomura N, Nakajima T, Uchiyama H. Assimilative and co-metabolic degradation of chloral hydrate by bacteria and their bioremediation potential. J Biosci Bioeng. 2011;111:448-53.

51. Baron JL, Vikram A, Duda S, Stout JE, Bibby K. Shift in the microbial ecology of a hospital hot water system following the introduction of an on-site monochloramine disinfection system. PLoS One. 2014;9:e102679. 2014/07/18.

52. Wrighton KC, Agbo P, Warnecke F, Weber KA, Brodie EL, DeSantis TZ, et al. A novel ecological role of the Firmicutes identified in thermophilic microbial fuel cells. ISME J. 2008;2:1146-56. Nature Publishing Group. Available from: http://www.nature.com/doifinder/10.1038/ismej.2008.48. [cited 2016 Oct 19].

53. Sohn JH, Kwon KK, Kang J-H, Jung H-B, Kim S-J. Novosphingobium pentaromativorans sp. nov., a high-molecular-mass polycyclic aromatic hydrocarbon-degrading bacterium isolated from estuarine sediment. Int J Syst Evol Microbiol. 2004;54:1483-7. Microbiology Society. Available from: http://ijs. microbiologyresearch.org/content/journal/ijsem/10.1099/ijs.0.02945-0. [cited 2016 Oct 16].

54. Leroi AM, Bennett AF, Lenski RE. Temperature acclimation and competitive fitness: an experimental test of the beneficial acclimation assumption. Proc Natl Acad Sci U S A. 1994;91:1917-21. National Academy of Sciences. Available from: http://www.ncbi.nlm.nih.gov/ pubmed/8127906. [cited 2017 Aug 4].

55. Gião MS, Wilks SA, Keevil CW. Influence of copper surfaces on biofilm formation by Legionella pneumophila in potable water. Biometals. 2015;28: 329-39. Springer Netherlands. Available from: http://link.springer.com/10. 1007/s10534-015-9835-y. [cited 2016 Oct 15].

56. Lu J, Buse HY, Gomez-Alvarez V, Struewing I, Santo Domingo J, Ashbolt NJ. Impact of drinking water conditions and copper materials on downstream biofilm microbial communities and Legionella pneumophila colonization. J Appl Microbiol. 2014;117:905-18. 2014/06/18.

57. Scheikl U, Sommer R, Kirschner A, Rameder A, Schrammel B, Zweimüller I, et al. Free-living amoebae (FLA) co-occurring with Legionellae in industrial waters. Eur J Protistol. 2014;50:422-9. Elsevier. Available from: http://www. ncbi.nlm.nih.gov/pubmed/25062389. [cited 2016 Oct 16]. 
58. Marciano-Cabral F, Jamerson M, Kaneshiro ES. Free-living amoebae, Legionella and Mycobacterium in tap water supplied by a municipa drinking water utility in the USA. J Water Health. 2010;8:71-82. Available from: http://www.ncbi.nlm.nih.gov/pubmed/20009249. [cited 2016 Oct 16]

59. Eberspächer J, Lingens F. The genus Phenylobacterium, The Prokaryotes. New York: Springer New York; 2006. p. 250-6. Available from: http://link. springer.com/10.1007/0-387-30745-1_13. [cited 2016 Oct 16].

60. Campbell BJ. The family Acidobacteriaceae, The Prokaryotes. Berlin: Springer Berlin Heidelberg; 2014. p. 405-15. Available from: http://link.springer.com/ 10.1007/978-3-642-38954-2_160. [cited 2016 Oct 16].

61. Oren A, Xu X-W. The family Hyphomicrobiaceae, The Prokaryotes. Berlin: Springer Berlin Heidelberg; 2014. p. 247-81. Available from: http://link. springer.com/10.1007/978-3-642-30197-1_257. [cited 2016 Oct 16].

62. Teitzel GM, Geddie A, De Long SK, Kirisits MJ, Whiteley M, Parsek MR. Survival and growth in the presence of elevated copper: transcriptional profiling of copper-stressed Pseudomonas aeruginosa. J Bacteriol. 2006;188: 7242-56. American Society for Microbiology. Available from: http://www. ncbi.nlm.nih.gov/pubmed/17015663. [cited 2016 Oct 16].

63. Buse HY, Lu J, Struewing IT, Ashbolt NJ. Preferential colonization and release of Legionella pneumophila from mature drinking water biofilms grown on copper versus unplasticized polyvinylchloride coupons. Int J Hyg Environ Health. 2014;217:219-25. Available from: http://www.sciencedirect.com/ science/article/pii/S143846391300059X. [cited 2015 Jan 22].

64. Moritz MM, Flemming HC, Wingender J. Integration of Pseudomonas aeruginosa and Legionella pneumophila in drinking water biofilms grown on domestic plumbing materials. Int J Hyg Env Heal. 2010;213:190-7. 2010/06/18

65. Lin Y-S, Vidic RD, Stout JE, Yu VL. Negative effect of high $\mathrm{pH}$ on biocidal efficacy of copper and silver ions in controlling Legionella pneumophila. Appl Environ Microbiol. 2002;68:2711-5. American Society for Microbiology. Available from: http://www.ncbi.nlm.nih.gov/pubmed/12039724. [cited 2016 Oct 15].

66. Boulay N, Edwards M. Role of temperature, chlorine, and organic matter in copper corrosion by-product release in soft water. Water Res. 2001;35:683-90

67. Wen G, Kötzsch S, Vital M, Egli T, Ma J. BioMig — a method to evaluate the potential release of compounds from and the formation of biofilms on polymeric materials in contact with drinking water. Environ Sci Technol. 2015;49:11659-69. American Chemical Society. Available from: http://pubs. acs.org/doi/10.1021/acs.est.5b02539. [cited 2015 Dec 2].

68. van der Wielen PWJJ, van der Kooij D. Nontuberculous mycobacteria, fungi, and opportunistic pathogens in unchlorinated drinking water in The Netherlands. Appl Environ Microbiol. 2013;79:825-34. American Society for Microbiology. Available from: http://www.ncbi.nlm.nih.gov/pubmed/ 23160134. [cited 2016 Oct 16].

69. Meier T, Bendinger B. Survival of pathogens in drinking water plumbing systems: impact factors and sanitation options. Water Sci Technol Water Supply. 2016;2016:ws2016040. IWA Publishing. Available from: http://ws. iwaponline.com/cgi/doi/10.2166/ws.2016.040. [cited 2016 Jul 4].

70. Temmerman R, Vervaeren $H$, Noseda B, Boon N, Verstraete W. Necrotrophic growth of Legionella pneumophila. Appl Environ Microbiol. 2006;72:4323-8. American Society for Microbiology. Available from: http://www.ncbi.nlm.nih. gov/pubmed/16751547. [cited 2016 Oct 16].

71. Thomas JM, Ashbolt NJ. Do free-living Amoebae in treated drinking water systems present an emerging health risk? Environ. Sci. Technol. 2011;45: 860-9. American Chemical Society. Available from: http://pubs.acs.org/doi/ abs/10.1021/es102876y. [cited 2016 Oct 16].

\section{Submit your next manuscript to BioMed Central and we will help you at every step:}

- We accept pre-submission inquiries

- Our selector tool helps you to find the most relevant journal

- We provide round the clock customer support

- Convenient online submission

- Thorough peer review

- Inclusion in PubMed and all major indexing services

- Maximum visibility for your research

Submit your manuscript at www.biomedcentral.com/submit 